\title{
Microcos magnifica (Sparrmanniaceae) a new species of cloudforest tree from Cameroon
}

\author{
Martin Cheek ${ }^{\text {Corresp. } 1}$ \\ ${ }^{1}$ Identification \& Naming, Science, Royal Botanic Gardens, Kew \\ Corresponding Author: Martin Cheek \\ Email address: m.cheek@kew.org
}

Background: Although many new species to science have been discovered from thousands of specimens resulting from botanical inventories to support conservation management in Cameroon in recent years, additional species remain to be formally evaluated taxonomically and described. These include species from genera which have been taxonomically neglected for many decades in Africa, such as Microcos. Methods: This study is based mainly on herbarium specimens and field observations made in Cameroon during a series of botanical surveys. Herbarium material was examined with a Leica Wild M8 dissecting binocular microscope fitted with an eyepiece graticule. Principal findings: Microcos magnifica Cheek (Malvaceae-Grewioideae or Sparrmanniaceae) is described as an Endangered (EN B2 ab(iii)) new tree species from the submontane forests of Cameroon. It is illustrated and described, and its conservation status and taxonomic affinities are assessed. It is the first new Microcos described from Africa in more than 90 years and is unique on the continent in having sculptured fruits. Discussion: A systematic revision, with a molecular phylogenetic study, of Microcos Burm. ex L.in Africa is necessary if the affinities of the species, including M. magnifica, are to be reliably established. 
1 Microcos magnifica (Sparrmanniaceae) a new species of cloudforest tree from Cameroon.

2

3

4

Martin Cheek ${ }^{1}$

${ }^{1}$ Identification \& Naming, Science, Royal Botanic Gardens, Kew. m.cheek@kew.org

\section{ABSTRACT.}

Background: Although many new species to science have been discovered from thousands of specimens resulting from botanical inventories to support conservation management in Cameroon in recent years, additional species remain to be formally evaluated taxonomically and described. These include species from genera which have been taxonomically neglected for many decades in Africa, such as Microcos.

Methods: This study is based mainly on herbarium specimens and field observations made in Cameroon during a series of botanical surveys. Herbarium material was examined with a Leica Wild M8 dissecting binocular microscope fitted with an eyepiece graticule.

Principal findings: Microcos magnifica Cheek (Malvaceae-Grewioideae or Sparrmanniaceae) is described as an Endangered (EN B2 ab(iii)) new tree species from the submontane forests of Cameroon. It is illustrated and described, and its conservation status and taxonomic affinities are assessed. It is the first new Microcos described from Africa in more than 90 years and is unique on the continent in having sculptured fruits.

Discussion: A systematic revision, with a molecular phylogenetic study, of Microcos Burm. ex L.in Africa is necessary if the affinities of the species, including M. magnifica, are to be reliably established.

\section{INTRODUCTION}

During identification of specimens resulting from botanical surveys of Mt Kupe and the Bakossi Mts in SW Region, Cameroon, specimens of a remarkable undescribed Microcos Burm. ex L. (1753) came to light, which were designated as Microcos sp. A (Cheek in Cheek et al. 2004: 414). Subsequently an additional specimen was discovered in the forests of Ebo, Littoral Region. Here these specimens are formally named as Microcos magnifica Cheek, the first new species to science to be described in the genus for Africa for 90 years. The species is remarkable for its sculptured fruit surfaces which are verrucate. Sculptured fruit surfaces are not otherwise known in the African species but do occur in some Asian species.

Microcos is a palaeotropical genus of about 77 species (Govaerts et al. continuously updated) based on M. paniculata Burm. ex L. (1753) from Sri Lanka. Linnaeus (1767) later synonymised Microcos under Grewia L. However, the genus was resurrected by Burret (1926).

Burret's authoritative revision (1926) of former Tiliaceae sens. lat. presaged its break-up into todays's Brownloideae/Brownlowiaceae, Tiliaceae sensu stricto/Tilioideae and Grewioideae/Sparrmanniaceae (with the largest number of genera and species) including Microcos (Bayer et al. 1999, Bayer \& Kubitzki 2003, Cheek 2007a-c). In addition, Schoutenia Korth.included by Burret in Tiliaceae, is now placed in Dombeyoideae/Pentapetaceae (Cheek 2007d). Burret's was the last global treatment of Microcos (1926). He recognised 53 species, of which 19 were recorded from Africa and 34 in Asia. Of the 99 names in Microcos listed in IPNI (continuously updated), Govaerts et al. (continuously updated) accept 77 names. The majority of these 77 are in S.E. Asia, but with 10 in Africa. The genus is absent from the Neotropics and Madagascar. 
50 Illogically, while Microcos has been maintained as a separate genus from Grewia in Asia (e.g. 51 Chung 2003, 2006, Chung et al. 2005a, Chung \& Soepadmo 2011), the two genera have often

52 been united under Grewia in Africa. For example, in one of the most recent Flora accounts of

53 Grewia (including Microcos) for Africa, Whitehouse (2001) states “...Kirkup followed Burret in

54 recognising Microcos as a distinct genus; this concept has also been followed in SE Asia.

55

56 Although there are clear differences between Microcos and the other sections of Grewia, for consistency I am following the practice set by the other African floras, of not recognising...." This practice is maintained widely today, for example by the excellent and essential African Plant Database (continuously updated).

In fact the two genera are readily recognised as expressed in the key below, modified from that in Whitehouse (2001):

Trees and climbers, rarely shrubs, of evergreen forest; stigmas entire; fruit unlobed; inflorescences terminal, sometimes axillary also, many-flowered......Microcos

Shrubs, rarely trees, of bushland or woodland; stigmas lobed; fruit 4-lobed, rarely entire; inflorescences usually axillary or leaf-opposed, rarely terminal, usually few-

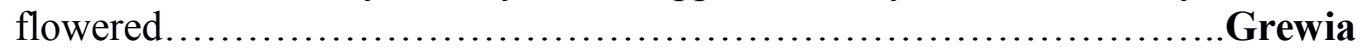

According to the molecular analysis of Brunken \& Muellner (2012), Microcos is not embedded in Grewia, neither are they sister groups, and they fall into distinct clades.

Additional characters for separating the two genera are found in the pollen, wood anatomy and in the leaf anatomy, particularly the epidermal cells (Chattaway 1934, Chung 2002, Chung et al. 2003, 2005b). Microcos was maintained in Bayer \& Kubitzki (2003).

The genus Microcos has been little studied in Africa, as evidenced by the fact that the first new name in African Microcos since 1926 was published in 2004 (Microcos barombiensis (K. Schum.) Cheek in Cheek et al.2004: 414). In the course of matching the material described as new in this paper, it became clear that a revision of the genus for Africa is desirable to address specimen misidentifications and additional apparently undescribed species. It is hoped to address these problems in a future paper.

\section{MATERIALS \& METHODS}

The electronic version of this article in Portable Document Format (PDF) will represent a published work according to the International Code of Nomenclature for algae, fungi, and plants (ICN), and hence the new names contained in the electronic version are effectively published under that Code from the electronic edition alone. In addition, new names contained in this work which have been issued with identifiers by IPNI will eventually be made available to the Global Names Index. The IPNI LSIDs can be resolved and the associated information viewed through any standard web browser by appending the LSID contained in this publication to the prefix "http://ipni.org/". The online version of this work is archived and available from the following digital repositories: PeerJ, PubMed Central, and CLOCKSS.

This study is based mainly on herbarium specimens and field observations made in Cameroon during a series of botanical surveys beginning in 1991. These surveys were mainly led by the author. So far they have resulted in 52,450 specimens being studied at K and YA, of which 
98

99

100

101

102

103

104

105

106

107

108

109

110

111

112

113

114

115

116

117

118

119

120

121

122

123

124

125

126

127

128

129

130

131

132

133

134

135

136

137

138

139

140

141

142

143

37,850 were newly collected, the data stored on the Kew Cameroon specimen Access database (Gosline, p. 11 in Cheek et al. 2004). The top set of specimens was initially deposited at SCA, and later YA, duplicates being sent to $\mathrm{K}$. The fieldwork was approved by the Institutional Review Board of the Royal Botanic Gardens, Kew entitled the Overseas Fieldwork Committee (OFC). The most the most recent OFC approval is numbered 807. The most recent invitation to effect research on the flora and vegetation of Cameroon has the reference number 050/IRAD/DG/CRRA-NK/SSRB-HN/09/2016. It is issued under the terms of the 5 year Memorandum of Collaboration between Institute for Research in Agricultural Development (IRAD)-Herbier National du Cameroun and Royal Botanic Gardens, Kew signed $5^{\text {th }}$ Sept 2014,

All specimens cited have been seen by the author unless indicated n.v. Herbarium citations follow Index Herbariorum (Thiers et al. continuously updated) and binomial authorities IPNI (continuously updated). Material of the suspected new species was compared morphologically with material of all other African Microcos (or Grewia sect. Microcos (L.)Wight \& Arnott) principally at K, but also using material from WAG. This comprised about 350 specimens. The online search address used for retrieving specimen data from labels at $\mathrm{P}$ was http://coldb.mnhn.fr/catalognumber/mnhn/p/po0375109. Burret's types of Microcos at B were destroyed by allied bombing in 1943 so it was not possible to consult them. This has necessitated that subsequent authors select neotypes of his names, e.g. Whitehouse (2001). The description follows the format of Whitehouse (2001).

The conservation assessment was made using the categories and criteria of IUCN (2012). The extent of occurrence was calculated with Geocat (Bachman et al. 2011). Herbarium material was examined with a Leica Wild M8 dissecting binocular microscope. This was fitted with an eyepiece graticule measuring in units of $0.025 \mathrm{~mm}$ at maximum magnification. The drawing was made with the same equipment using Leica 308700 camera lucida attachment.

\section{RESULTS}

KEY TO THE TREE SPECIES OF MICROCOS IN AFRICA WEST OF DEMOCRATIC REPUBLIC OF CONGO \& THE CONGO RIVER

1. Leaves deeply toothed. Maiombe Mts of Cabinda M. gossweileri Burret Leaves entire. Nigeria to Congo-Brazzaville, but unknown from Cabinda......................................................

2. Leaf base cuneate, leaf surfaces glabrous; fruits glossy, smooth........................................ coriacea Burret Leaf base truncate or cordate, leaf blade lower surface stellate hairy; fruits matt, verrucate. M. magnifica Cheek

Microcos magnifica Cheek species novum

Holotype: Cameroon, S.W. Province, Mt Kupe, Kupe village, main trail towards summit, fr. 9 July 1996, Etuge 2886 (holo. K; isotypes BR, K, MO, P, SCA, US, WAG, YA) (Figure 1, Figure 2)

Microcos sp. A, Cheek (in Cheek et al. 2004: 414). 
144

145

146

147

148

149

150

151

152

153

154

155

156

157

158

159

160

161

162

163

164

165

166

167

168

169

170

171

172

173

174

175

176

177

178

179

180

181

182

183

184

185

186

187

188

189

190

191
Tree 20-35 m tall, 30-70 cm diameter at breast height, crown small, bole straight, base of bole with 4-5 concave slender buttresses reaching 1 to $1.5 \mathrm{~m}$ above the ground where sometimes spreading up to $2.5 \mathrm{~m}$ from the trunk and branching.

Bark dull medium red- brown, fibrous; slash hard fibrous-granular, without scent or exudates, white, oxidising rapidly from white to red.

Leafy stems 3-5 mm diameter below the third node, finely longitudinally ridged, densely minutely grey-brown puberulent, internodes $2.5 \mathrm{~cm}$ long.

Leaves obovate, obovate-oblong or elliptic, 12.5-25.5 x 6.6-13.5 cm ( those of sterile stems large, to $28 \mathrm{~cm}$ long ), acumen $0.4-1.8 \mathrm{~cm}$ long, base truncate or truncate and abruptly cordate, margin entire, lateral nerves $11-13$ on each side of the midrib, the basal pair more conspicuous by virtue of a pair subsidiary nerves, brochidodromous domatia absent, tertiary nerves strongly scalariform, quaternary nerves inconspicuous: upper surface with midrib varied, convex, densely and minutely grey-brown puberulent, secondary nerves flat but also puberulent : lower surface with midrib and secondary nerves strongly raised, brownish green, the areolae pale green or brown/khaki densely puberulent with minute pale brown 8-20-armed stellate hairs $0.1-0.2 \mathrm{~mm}$ diameter, touching each other, more or less completely concealing the epidermis. Presumed shade leaves (larger, from sterile branches - Elad 118) with hairs sparse, separated by 1 or 2 hair diameters, smaller, 0.075-0.1 mm diameter, with only 6-8 (-12) arms. Petiole stout, cylindrical, $(1.5-) 1.8-2 \times 0.3 \mathrm{~cm}$. Stipules caducous, not seen, but leaving an arched scar $4 \mathrm{~mm}$ long on the stem each side and $1 \mathrm{~mm}$ below the insertion of the leaf base.

Inflorescence and flowers unknown. Infructescence terminal, paniculate, 11-16 x 5.5-13 $\mathrm{cm}$, bearing 5-13(-12) fruits; peduncle 1.5-2.7 cm; bracts not seen; pedicel absent, fruits articulated at junction with stem.

Fruits fleshy, red when live, drying pink-brown, obovoid to ellipsoid 2-2.4 x $1.2-1.5 \mathrm{~cm}$, verrucate and finely longitudinally wrinkled with $20-25$ verrucae, verrucae $0.5-1 \mathrm{~mm}$ long, patent. Mesocarp: outer part thin and fleshy, inner part thick and densely fibrous. Endocarp obovoid, slightly 3-angled, woody, whitish brown, sutures longitudinal, alternating with three lines of hairs; locule 1, probably by abortion from 3, 1-seeded.

Seed narrowly ovoid, glabrous, slightly laterally compressed, hilum subapical; endosperm extensive, embryo flattened.

Phenology: Fruiting: April to July; flowering: unknown.

Distribution and habitat: SW and Littoral Regions of Cameroon; submontane or submontanelowland forest with Medusandra mpomiana Letouzey \& Satabie, Santiria trimera (Oliv.) Aubrév., Allanblackia gabonensis (Pellegr.) Bamps, Coelocaryon preussii Warb. (Mt. Kupe); Pycnanthus Warb., Coelocaryon Warb. Staudtia Warb., Petersianthus Merr., Strombosia Blume and Maesobotrya Benth. (Ebo); 750-1000 m alt.

Etymology: Meaning magnificent, for the spectacular and unusual fruit ornamentation.

Affinity: Resembling Microcos coriacea Burret,but fruits verrucate and matt, not smooth and glossy; leaves with base truncate or cordate, not cuneate; lower surface densely white stellate hairy, not glabrous).

Additional specimens: South West Region. Mt Kupe, $15 \mathrm{Km}$ WNW de Tombel, colline 930m de NW de Ngussi, fr. 21 April 1976, Letouzey 14669 (P n.v.; YA 3 sheets); Mt Kupe, Nyasoso, trails above village, $4^{\circ} 49^{\prime} \mathrm{N}$; 9 $9^{\circ} 41^{\prime}$ 'E, st. 6 Feb. 1995, Elad 118 (K, YA n.v.); Nyasoso, Max's trail, fr. 3 June 1996, Cable 2806 (K, YA); Kupe village, main trail towards summit, fr. 9 July 1996, Etuge 2886 (holo. K; iso. BR, K, MO, P, SCA, US, WAG, YA). Littoral Region, Yingui, Ebo proposed National Park, 6 hours walk S. of Iboti village; between the abandoned villages of Bekob and Masseng, 42150 N; 102520 E, st. 16 Feb. 2006, Cheek 12980 (K, SCA, YA) 
192 Conservation: Microcos magnifica is here assessed as Endangered (EN B2 ab(iii)) using the

193 IUCN 2012 system, since it is known from four threat-based locations with an extent of

194 occurrence of $303 \mathrm{~km}^{2}$ calculated using Geocat (Bachman et al. 2011) and an area of occupancy

195 of $16 \mathrm{~km}^{2}$ using IUCN preferred $4 \mathrm{~km}^{2}$ grid cells. The species is threatened at all its known

196 locations, most immediately the three in the Mt Kupe area of Ngussi and Nyassoso where

197 clearance of forest continues upslope from the volcanic, fertile lowlands of the Chide valley. The

198 clearance is for small-holder agriculture, principally for food crops. The locations concerned are

199 all far outside the Mt Kupe Ecological Reserve and on the edges of towns. It is quite likely that

200 some or all of the trees that provided the specimens and the forest remnants in which they

201 occurred, have been cleared already (Cheek pers. obs.). In order to reduce the threat to the species

202 here, a local conservation poster featuring the species is intended in order to raise awareness of

203 the existence and importance of its protection. However, at the fourth location, in the proposed

204 Ebo National Park, the species is secure from immediate threat, there being no resident human

205 population. However, the future of Ebo as a protected area is not certain, and logging, plantation

206 and mining are all threatened as alternative uses for the land.

207 Since there is no indication that more than a single mature individual has ever been recorded at

208 each of the four locations, it is conceivable that Microcos magnifica might be better assessed as

209 Critically Endangered under Criterion D of IUCN (less than 50 mature individuals recorded).

210

211

212

213

214

215

216

217

218

219

220

221

222

223

224

225

226

227

228

229

230

231

232

233

234

235

236

237

238

239

240

\section{DISCUSSION}

The affinities of M. magnifica may be with the only two other arborescent species of Microcos that occur in West-Central Africa (see key to species above). The majority of Microcos species in Africa are scandent climbers, completely different in habit from the arborescent species. Of the arborescent species, only M. coriacea is sympatric with M. magnifica. At Mt Kupe the two species have differing altitudinal ranges, M. coriacea with a range of $200-420 \mathrm{~m}$, based on four records, and M. magnifica with 900-1000m, based on three records (Cheek in Cheek et al. 2004: 414). It can be postulated that $M$. magnifica has arisen as a submontane derivative of $M$. coriacea. However, among the taxa discovered as new at Mt Kupe at similar altitudes to $M$. magnifica was Kupea martinetugei Cheek (Cheek et al. 2003) which has its sister species in the Eastern Arc Mts of Tanzania (Cheek 2004).

Exactly the same geographic range as Microcos magnifica, which extends disjunctly from the western slopes of Mt Kupe to the submontane N-S ridge of the Ebo forest, is seen also in Uvariopsis submontana Kenfack (Kenfack et al. 2003) and Costus kupensis H.Maas \& Maas (Maas-van de Kamer et al. 2016). It is remarkable that none of these conspicuous species has been discovered in the submontane ridge of the Ngovayang massif to the east at Bipindi, nor in the Bakossi Mts, immediately West of Mt Kupe, despite significant botanical surveys in these areas by Zenker and by K-YA teams respectively. This suggests that these distributions are real and not the result of undercollecting. However, all of these species are infrequent and only known from three to six specimens in as many locations.

The discovery of such a distinctive new species in the Kupe-Bakossi, Ebo and adjoining areas is not unusual. Among other species discovered here were (in alphabetical order by genus): Allophylus ujori Cheek (Cheek \& Etuge 2009a), Ancistrocladus grandiflorus Cheek (Cheek 2000), Brachystephanus kupeensis Champl. (Champluvier \& Darbyshire 2009), Chassalia laikomensis Cheek (Cheek \& Csiba 2000), Coffea montekupensis Stoff. (Stoffelen et al. 1997), Coffea bakossii Cheek \& Bridson (Cheek et al. 2002), Cola metallica Cheek (Cheek 2002), Coleochloa domensis Muasya \& D.A. Simpson (Muasya et al. 2010), Deinbollia oreophila Cheek 
241 (Cheek \& Etuge 2009b), Diospyros kupensis Gosline (Gosline \& Cheek 1998); Dovyalis

242 cameroonensis Cheek \& Ngolan (Cheek \& Ngolan 2007), Dracaena kupensis Mwachala, Cheek,

243 Eb. Fisch. et al. (Mwachala et al. 2007), Impatiens etindensis Cheek \& Eb. Fisch. (Cheek \&

244 Fischer 1999), Impatiens frithii Cheek (Cheek \& Csiba 2002b), Isoglossa dispersa I.Darbysh.

245 (Darbyshire et al. 2011), Kupea martinetugei Cheek \& S.A.Williams (Cheek et al. 2003),

246 Ledermanniella onanae Cheek (Cheek 2003), Ledermanniella pollardiana Cheek \& Ameka

247 (Cheek \& Ameka 2008), Memecylon kupeanum R.D.Stone, Ghogue \& Cheek (R.D.Stone et al.

248 2008), Mussaenda epiphytica Cheek (Cheek 2009), Newtonia duncanthomasii Mackinder \&

249 Cheek (Mackinder \& Cheek 2003), Oxyanthus okuensis Cheek \& Sonké (Cheek \& Sonké 2000),

250 Psychotria darwiniana Cheek (Cheek et al. 2009), Psychotria geophylax Cheek \& Sonké and $P$.

251 bakossiensis Cheek \& Sonké (2005), Psychotria kupensis Cheek (Cheek et al. 2008), Psychotria

252 moseskemei Cheek (Cheek \& Csiba 2002a), Rhaptopetalum geophylax Cheek \& Gosline (Cheek

253 et al. 2002) and Ternstroemia cameroonensis Cheek (Cheek et al. 2017).

254

255

256

257

258

259

260

261

262

263

264

265

266

267

268

269

270

271

272

273

274

275

276

277

278

279

280

Most of these species are threatened with extinction, since they are narrow endemics with small ranges, restricted to mainly submontane (cloud) forest which is steadily being cleared, mainly for small-scale cultivation of food crops. These species feature in the Red Data Book of Cameroon (Onana \& Cheek 2011).

\section{CONCLUSIONS}

A systematic revision, with a molecular phylogenetic study, of Microcos in Africa is necessary if the affinities of the species, including M. magnifica, are to be reliably established.

Acknowledgements

Bate Oben is thanked for assisting by making morphological measurements. Xander van der Burgt assisted digitising the image. George Gosline is thanked for producing the map, and Saba Rokni for providing the Geocat analysis. Gaston Achoundong, Jean-Michel Onana, former heads of the National Herbarium of Cameroon (YA) and their successor Marie Florence Ngo Ngwe are thanked for their collaboration and support of the Royal Botanic Gardens, Kew's activities over the years. Laurence J. Dorr and two other, anonymous, reviewers are thanked for their constructive comments on an earlier version of this manuscript.

\section{References}

African Plant Database (version 3.4.0). (continuously updated). Conservatoire et Jardin botaniques de la Ville de Genève and South African National Biodiversity Institute, Pretoria, "Retrieved [March 2017]", from < $\underline{\text { http://www.ville-ge.ch/musinfo/bd/cjb/africa/>. }}$.

Bachman S, Moat J, Hill A, de la Torre J, Scott B. 2011. Supporting Red List threat assessments with GeoCAT: geospatial conservation assessment tool. ZooKeys 150: 117126. https://doi.org/10.3897/zookeys.150.2109

Bayer C, Fay MF, De Bruijn AY, Savolainen V, Morton CM, Kubitzki K, Alverson WS, Chase MW. 1999. Support for an expanded family concept of Malvaceae within a recircumscribed order Malvales: a combined analysis of plastid atpB and rbcL DNA sequences. Botanical Journal of the Linnean Society 129: 267-303. 
290

291

292

293

294

295

296

297

298

299

300

301

302

303

304

305

306

307

308

309

310

311

312

313

314

315

316

317

318

319

320

321

322

323

324

325

326

327

328

329
Bayer C, Kubitzki K. 2003. Malvaceae. In: Kubitzki K, Bayer C (eds), The

families and genera of vascular plants 5: flowering plants dicotyledons: 225-311. Springer-Verlag, Berlin.

Brunken U, Muellner AN. 2012. A new tribal classification of Grewioideae (Malvaceae) based on morphological and molecular phylogenetic evidence. Systematic Botany 37(3):699-711.

http://www.bioone.org/doi/full/10.1600/036364412X648670

Burret M. 1926. Beiträge zur Kenntnis der Tiliaceae I. Notizblatt des Königlich-

Botanischen Gartens und Museums zu Berlin-Dahlem 9: 592-880.

Champluvier D, Darbyshire I. 2009. A revision of the genera Brachystephanus and Oreacanthus (Acanthaceae) in tropical Africa. Systematics and Geography of Plants 79(2):115-192. DOI: $10.2307 / 25746$

Chattaway MM. 1934. Anatomical evidence that Grewia and Microcos are distinct genera. Tropical Woods 38: 9-11

Cheek M. 2000. A synoptic revision of Ancistrocladus (Ancistrocladaceae) in Africa, with a new species from western Cameroon. Kew Bulletin 55: 871-882. https://doi.org/10.2307/4113632

Cheek M. 2002. Three new species of Cola (Sterculiaceae) from western Cameroon, Cameroon. Kew Bulletin 57: 402-415. https://doi.org/10.2307/4111117

Cheek M. 2003. A new species of Ledermanniella (Podostemaceae) from western Cameroon. Kew Bulletin 58: 733-737. DOI: 10.2307/4111153

Cheek M. 2004. Kupeaeae, a new tribe of Triuridaceae from Africa. Kew Bulletin 58: 939-949. https://doi.org/10.2307/4111207

Cheek M. 2007a. Brownlowiaceae. In: Heywood VH, Brummitt RK, Culham A, Seberg O (eds), Flowering plant families of the world: 71. Royal

Botanic Gardens, Kew

Cheek M. 2007b. Tiliaceae. In: Heywood VH, Brummitt RK, Culham

A, Seberg O (eds), Flowering plant families of the world: 321-322. Royal

Botanic Gardens, Kew

Cheek M. 2007c. Sparrmanniaceae. In: Heywood VH, Brummitt RK, Culham

A, Seberg O (eds), Flowering plant families of the world: 307-308. Royal

Botanic Gardens, Kew 
330 Cheek M. 2007d. Pentapetaceae. In: Heywood VH, Brummitt RK, Culham

331 A, Seberg O (eds), Flowering plant families of the world: 247-248. Royal

332 Botanic Gardens, Kew

333

334

335

336

337

338

339

340

341

342

343

344

345

346

347

348

349

350

351

352

353

354

355

356

357

358

359

360

361

362

363

364

365

366

367

368

369

370

Cheek M. 2009. Mussaenda epiphytica sp. nov. (Rubiaceae) an epiphytic shrub from cloud forest of the Bakossi Mts, western Cameroon. Nordic Journal of Botany 27(6): 456 -459.

https://doi.org/10.1111//.1756-1051.2009.00576.x

Cheek M, Ameka G. 2008. Ledermanniella pollardiana sp.nov.(Podostemaceae) from western Cameroon. Nordic Journal of Botany 26: 214-217. DOI: 10.1111/j.1756-1051.2008.00162.x

Cheek M, Csiba L, Bridson D. 2002. A new species of Coffea (Rubiaceae) from western Cameroon. Kew Bulletin 57: 675-680. https://doi.org/10.2307/4110998

Cheek M, Corcoran M, Horwath A. 2009. Four new submontane species of Psychotria (Rubiaceae) with bacterial nodules from western Cameroon. Kew Bulletin 63: 405-418. https://doi.org/10.1007/s12225-008-9056-4.

Cheek M, Csiba L. 2000. A new species and new combination in Chassalia (Rubiaceae) of western Cameroon. Kew Bulletin 55: 883-888. DOI: 10.2307/4113633

Cheek M, Csiba L. 2002a. A revision of the Psychotria chalconeura complex (Rubiaceae) in Guineo-Congolian Africa. Kew Bulletin 57: 375-387. DOI: 10.2307/4111113

Cheek M, Csiba L. 2002b. A new epiphytic species of Impatiens (Balsaminaceae) from western Cameroon. Kew Bulletin 57(3): 669-674. DOI: 10.2307/4110997

Cheek M, Etuge M. 2009a. Allophylus conraui (Sapindaceae) reassessed and Allophylus ujori described from western Cameroon. Kew Bulletin 64(3): 495-502. doi:10.1007/s12225-009-9139$\mathrm{x}$

Cheek M, Etuge M. 2009b. A new submontane species of Deinbollia (Sapindaceae) from Western Cameroon and adjoining Nigeria. Kew Bulletin 64(3): 503-508. doi:10.1007/s12225009-9132-4

Cheek M, Fischer E. 1999. A tuberous and epiphytic new species of Impatiens (Balsaminaceae) from Southwest Cameroon. Kew Bulletin 54(2): 471-475. https://doi.org/10.2307/4115828.

Cheek M, Gosline G, Csiba L. 2002. A new species of Rhaptopetalum (Scytopetalaceae) from western Cameroon. Kew Bulletin 57(3): 661-667. DOI: 10.2307/4110996

371

372

Cheek M, Horwath A, Haynes D. 2008. Psychotria kupensis (Rubiaceae) a new dwarf, litter gathering species from western Cameroon. Kew Bulletin 63: 243-246.

373 https://doi.org/10.1007/s12225-008-9018-x.

375

376

377

Cheek M, Ngolan R. 2007. A reassessment of the Dovyalis spinosissima Gilg (Flacourtiaceae) complex in Africa, with a new species from Cameroon. Kew Bulletin 61: 595-600.

http://www.jstor.org/stable/20443304 
378

379

380

381

382

383

384

385

386

387

388

389

390

391

392

393

394

395

396

397

398

399

400

401

402

403

404

405

406

407

408

409

410

411

412

413

414

415

416

417

418

419

420

421

422

423

424

425
Cheek M, Pollard BJ, Darbyshire I, Onana J-M, Wild C. 2004. The Plants of Kupe, Mwanenguba and the Bakossi Mountains, Cameroon. A Conservation Checklist. Royal Botanic Gardens, Kew. London.

Cheek M, Sonké B. 2000. A new species of Oxyanthus (Rubiaceae-Gardeniinae) from western Cameroon. Kew Bulletin 55: 889-893. DOI: 10.2307/4113634

Cheek M, Sonké B. 2005. Two further new species of Psychotria (Rubiaceae) from western Cameroon. Kew Bulletin 60: 293-300. Stable URL: http://www.jstor.org/stable/4110940

Cheek M, Tchiengue B, Tacham WN. 2017. Ternstroemia cameroonensis (Ternstroemiaceae), a new medicinally important species of montane tree, nearly extinct in the Highlands of Cameroon. Blumea 62, 2017: 53 - 57. DOI: https://doi.org/10.3767/000651917X695362.

Cheek M, Williams S, Etuge M. 2003. Kupea martinetugei, a new genus and species of

Triuridaceae from western Cameroon. Kew Bulletin 58: 225-228. DOI: 10.2307/4119366

Chung RCK. 2002. Leaf epidermal micromorphology of Grewia L. and Microcos

L. (Tiliaceae) in Peninsular Malaysia and Borneo. Gardens'Bulletin

Singapore 54: 263-286.

Chung RCK. 2003. New taxa and new combinations of Microcos (Tiliaceae)

from Peninsular Malaysia and Borneo. Kew Bulletin 58: 329-349.

Chung RCK. 2006. A revision of Grewia (Malvaceae-Grewioideae) in Peninsular Malaysia and Borneo. Edinburgh Journal of Botany 62: 1-27.

Chung RCK, Lim SC, Lim AL, Soepadmo E. 2005b. Wood anatomy of Grewia and Microcos from Peninsular Malaysia and Borneo. Journal of Tropical

Forest Science 17: 175-196.

Chung RCK, Soepadmo E, Lim AL. 2003. The significance of pollen morphology in the taxonomy of Grewia and Microcos (Tiliaceae) in Peninsular

Malaysia and Borneo. Gardens' Bulletin Singapore 55: 239-256.

Chung RCK, Soepadmo E, Lim AL. 2005a. A synopsis of the Bornean species of Microcos L. (Tiliaceae). Gardens'Bulletin Singapore 57: 103-132.

Chung RCK, Soepadmo E. 2011. Taxonomic revision of the genus Microcos (MalvaceaeGrewioideae) in Peninsular Malaysia and Singapore. Blumea 56: 273-299. http://dx.doi.org/10.3767/000651911X619704

Darbyshire I, Pearce L, Banks H. 2011. The genus Isoglossa (Acanthaceae) in West Africa. Kew Bulletin 66 (3): 425-439. DOI: 10.1007/s12225-011-9292-x

Gosline G, Cheek M. 1998. A new species of Diospyros (Ebenaceae) from Southwest Cameroon. Kew Bulletin 53(2): 461-465 DOI: $10.2307 / 4114512$ 
426

427

428

429

430

431

432

433

434

435

436

437

438

439

440

441

442

443

444

445

446

447

448

449

450

451

452

453

454

455

456

457

458

459

460

461

462

463

464

465

466

467

468

469

470

471

472
Govaerts, RHA, Belyaeva I, Hartley H, Lindon H. (continuously updated). Microcos Burm. ex L.in: Plants of the World Online. Kew Science. powo.science.kew.org/taxon/urn:1sid:ipni.org:names:328157-2

IPNI (continuously updated).The International Plant Names Index. http://ipni.org/.

IUCN. 2012. IUCN Red List Categories and Criteria: Version 3.1. Second edition. Gland, Switzerland and Cambridge, UK: IUCN. Available from: http://www.iucnredlist.org/ (accessed: 01/2017).

Kenfack D, Gosline G, Gereau, RE, Schatz G. 2003. The genus Uvariopsis in Tropical Africa, with a recombination and one new species from Cameroon. Novon 13:443-449

Linnaeus C. 1753. Species plantarum. Salvii, Stockholm.

Linnaeus C. 1767. Systema naturae ed. 12, 1, 2. Salvii, Stockholm.

Mackinder B, Cheek M. 2003. A new species of Newtonia (Leguminosae-Mimosoideae) from Cameroon. Kew Bulletin 58: 447-452. DOI: 10.2307/4120627

Maas-van de Kamer H, Maas PJM, Wieringa JJ, Specht CD. 2016. Monograph of African Costus. Blumea - Biodiversity, Evolution and Biogeography of Plants 61 (3): 280-318. DOI: https://doi.org/10.3767/000651916X694445

Muasya A, Harvey YH, Cheek M, Tah K, Simpson DA. 2010. A new species of epiphytic Coleochloa (Cyperaceae) from Cameroon. Kew Bulletin 65: 1-3. DOI: 10.1007/s12225-0109194-3

Mwachala G, Cheek M, Fischer E, Muasya AM. 2007. A new species of Dracaena L. (Ruscaceae) from Cameroon. Kew Bulletin 64: 613-616. http://www.jstor.org/stable/20443393

Onana J-M, Cheek M. 2011. The Red Data Book, Plants, of Cameroon. Royal Botanic Gardens, Kew

Stoffelen P, Cheek M, Bridson D, Robbrecht E. 1997. A new species of Coffea (Rubiaceae) and notes on Mt Kupe (Cameroon). Kew Bulletin 52(4): 989-994. DOI: 10.2307/3668527

Stone RD, Ghogue J-P, Cheek M. 2008. Revised treatment of Memecylon sect. Afzeliana (Melastomataceae-Olisbeoideae), including three new species from Cameroon. Kew Bulletin 63: 227-241. https://doi.org/10.1007/s12225-008-9033-y

Thiers B (continuously updated). Index Herbariorum: A global directory of public herbaria and associated staff. New York Botanical Garden's Virtual Herbarium. Available from: http://sweetgum.nybg.org/ih/ (accessed: Jan. 2017).

Whitehouse C. 2001. Grewia, pp. 7-63 in Whitehouse et al. Tiliaceae. Flora of Tropical East Africa. Royal Botanic Gardens, Kew. 
476 CAPTION FOR FIGURE.

477 Figure 1. Microcos magnifica A habit, fruiting branch; B habit sketch; C1-C3 leaf variation:

478 Etuge 2686: hairs on upper surface (left); hairs on lower surface (right). D1-D2 leaf variation:

479 Elad 118, with detail of hairs on lower surface; E1-E2 leaf variation: Cable 2806, with detail of 480 hairs on lower surface; $\mathbf{F}$ fruit, side view; $\mathbf{G}$ fruit, left with pericarp removed exposing mesocarp 481 fibres; right longitudinal section (endocarp stippled, endosperm densely stippled), H endocarp, 482 left, side view; right, distal end view; I endocarp with seed, transverse section. A, C, F-K from 483 Etuge 2686; B from field observations of Cheek 12980; D from Elad 128; E from Cable 2806. 484 All drawn by ANDREW BROWN.

Figure 2. Global distribution of Microcos magnifica. 


\section{Figure 1}

\section{Microcos magnifica}

A habit, fruiting branch; B habit sketch; C leaf variation: Etuge 2686: hairs on upper surface (left); hairs on lower surface (right). D leaf variation: Elad 118, with detail of hairs on lower surface; E leaf variation: Cable 2806, with detail of hairs on lower surface; F fruit, side view; G fruit, left with pericarp removed exposing mesocarp fibres; right longitudinal section (endocarp stippled, endosperm densely stippled), $\mathrm{H}$ endocarp, left, side view; right, distal end view; I endocarp with seed, transverse section. A, C, F-K from Etuge 2686; B from field observations of Cheek 12980; D Elad 128; E Cable 2806. All drawn by Andrew Brown. 


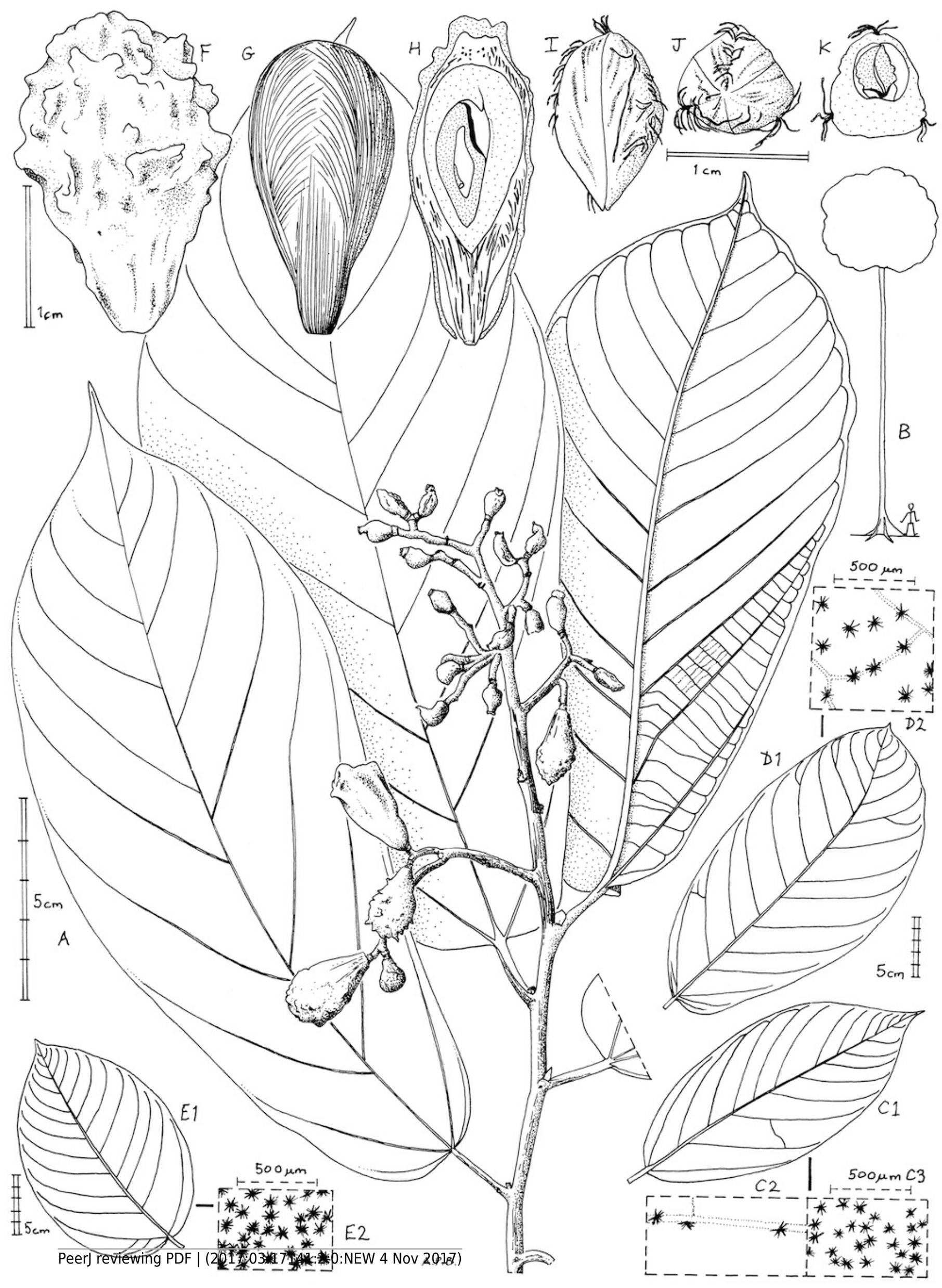


Figure 2

Global distribution of Microcos magnifica.

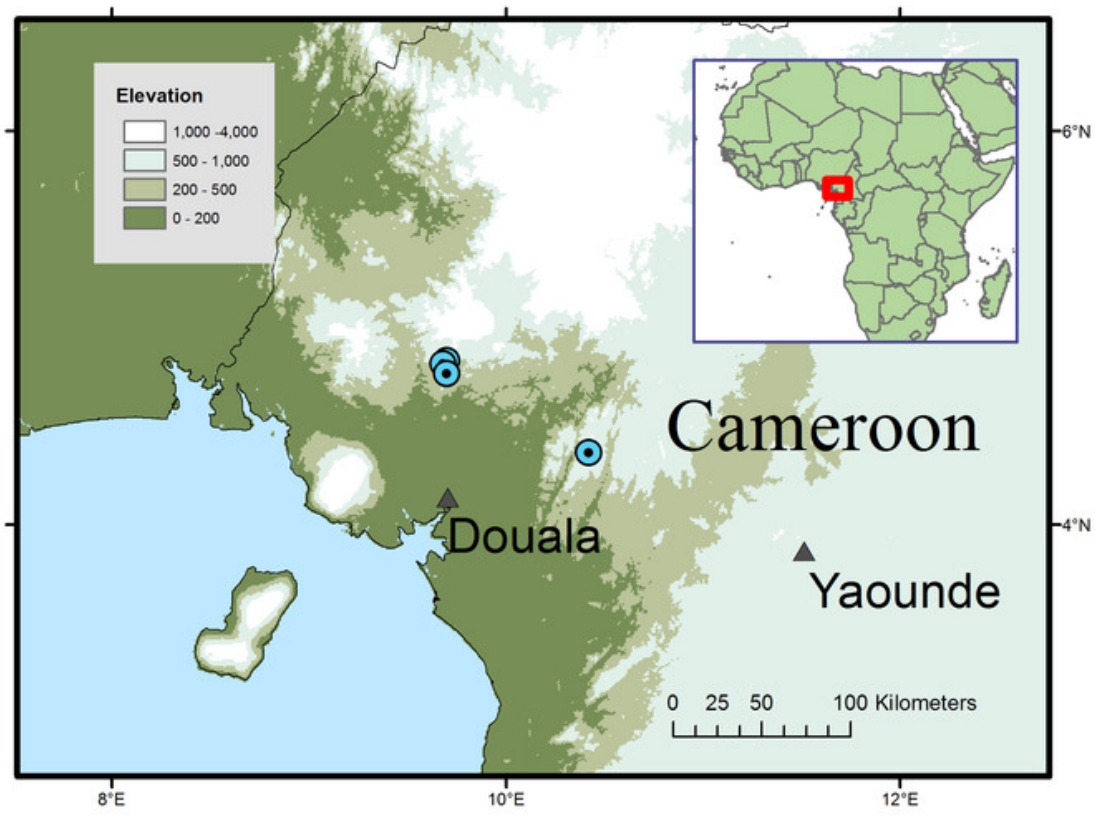

